\title{
المهارات الاجتماعية لدى الأطفال
}

\author{
(إعراد \\ الباحثة / ساره محمد حسن حواس \\ باحثت ماجستير
}

$$
\text { أر افـ }
$$

أ. د/ محمل حسين محمد سعل اللدين الحسيني

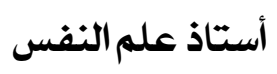

بكليت الآداب - جامعت المنصورة

المجلت العلميت لكليت رياض الأطفال ـ جامعت المنصورة

$$
\text { المجلد السادس ـ العدد الثانى }
$$




\section{المهارات الاجتماعية لدى الأطفال}

أ / ساره محمد حسن حواس*

يرجع الاهنمام بالمهار ات الاجتماعية إلى كونها من ركائز التو افق النفسي على المستوى الثخصي و المجتمعي وذلك من منطلق أن إقامة علاقات ودية من بين المؤشر ات الهامة للكفاءة في العلاقات الشخصية فالفرد كما بُشـشير كـاريون

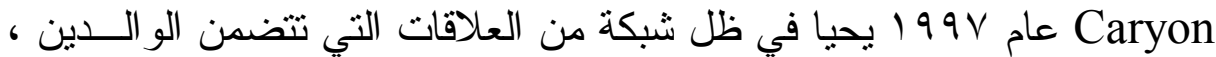
و الأقر ان ، و الأقارب ، و المعلمين ، ومن ثم فإن نمو تللك المهــار ات ضــروري للشروع في إقامة علاقات شخصية ناجحة، ومستمرة معسـه ـ (أحمــد داهـــ ،

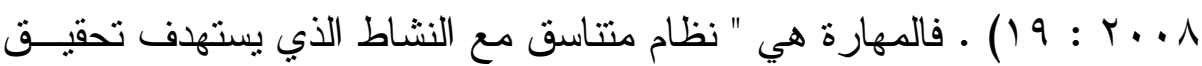
هدف معين ، وتصبح المهارة اجتماعية ، عندما يتفاعل فرد مع آخـر ، ويقـوم بنشاط اجتماعي يتطلب مهارة ليو ائم بين ما يقوم به الفرد الآخر وبين ما يفعلـــه هو ، وليصحح مسار نشاطه ليحقق بذلك هذه المو ائمة " .(الـسيد أبــو هاثـــم ، $\cdot(1 \leq 9: r \ldots r$

\section{1 - مفهوم المهار ات الاجتماعية :}

ليس هنالك تعريف محدد للمهار ات الاجتماعية نظر اً لاتساع هذا المفهــوم من جهة ، وما يطر أ على هذا المفهوم من تغبير ، بسبب التغيير العلمي المستمر في هذا المجال من جهة أخري .

" باحثتماجستير.




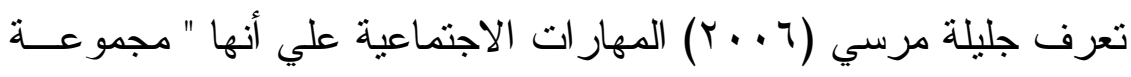

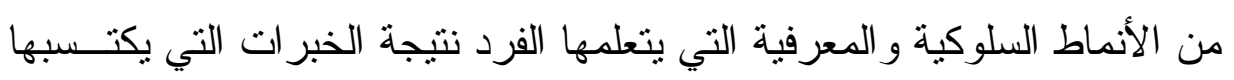

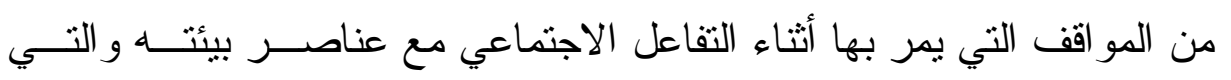

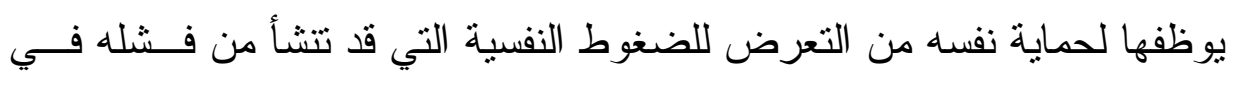

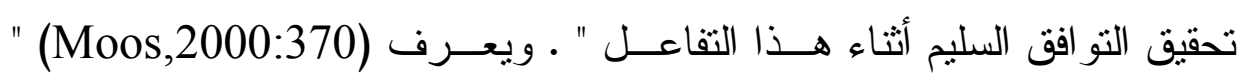

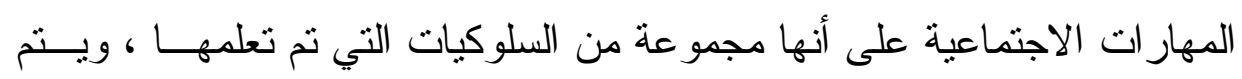

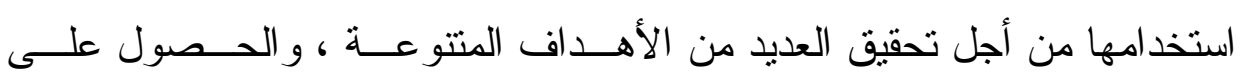

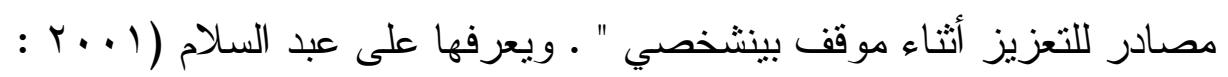

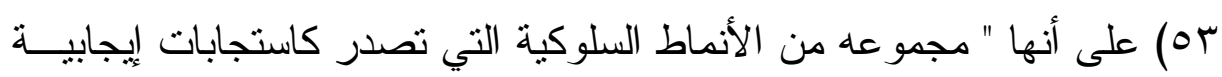

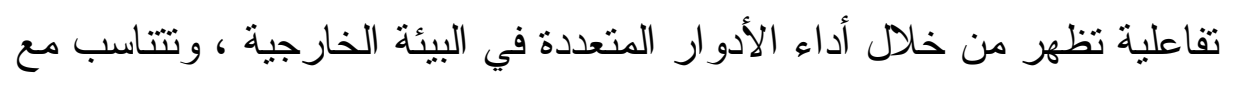

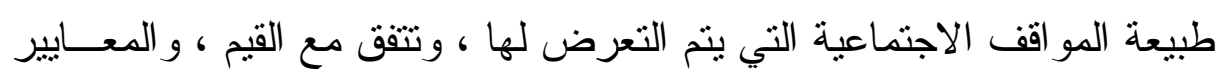

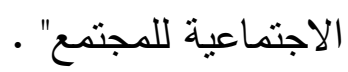

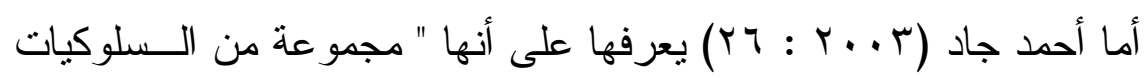

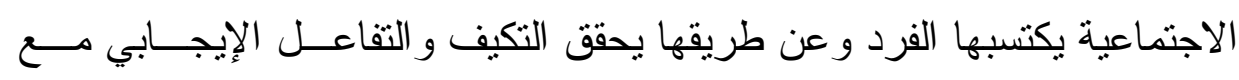

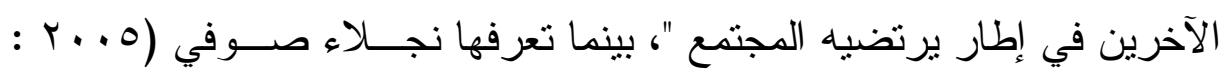

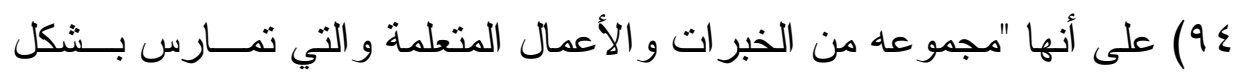

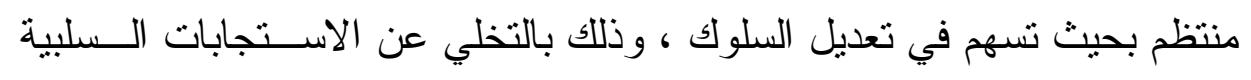
الغير مقبولة اجتماعياً ، وممارسة الاستجابات الإيجابية المقبولة اجتماعياً كالتقليد

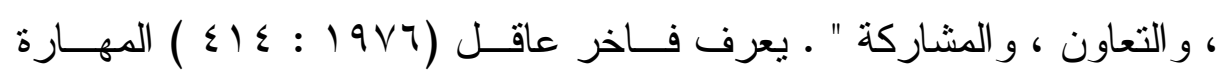

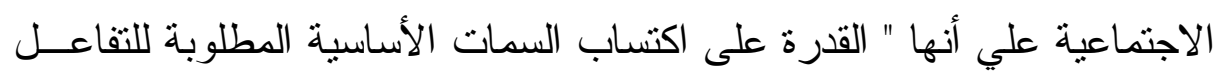

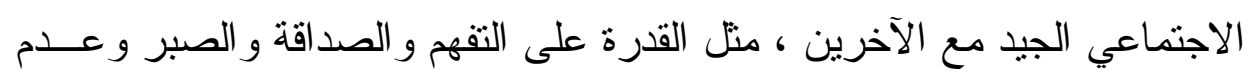

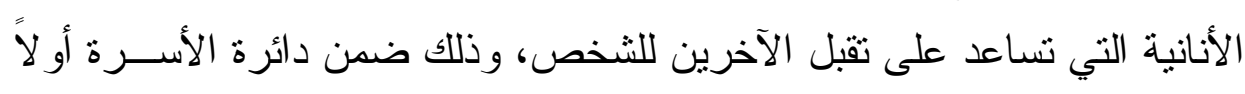




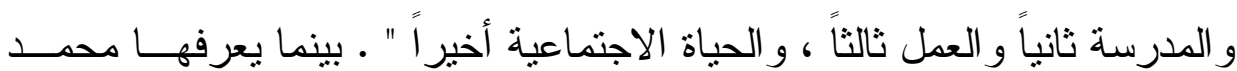
عبد الرحمن (1991 19 : 17) " علي أنها القدرة علــى المبــادأة بالتقاعـلـل مــع الآخرين ، و التعبير عن المشاعر السلبية ، و الإيجابية إز اءهم وضــبط انفعالاتــهـ في مو اقف التفاعل الاجتماعي ، وبما يتتاسب مع طبيعة الموقف " ـ أمــا الـسيد

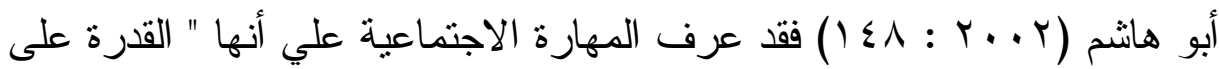
القيادة والاتصال مع الأفر اد الآخرين لإنجاز أهداف محددة " .

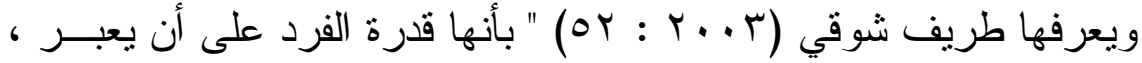

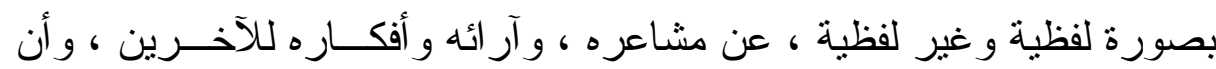
ينتبه ويدرك في الوقت نفسه الرسائل اللفظية وغير اللفظية الــصـادرة عــنهم ،

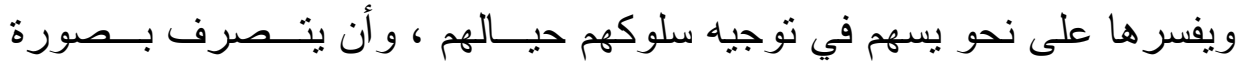
ملائمة في مو اقف التفاعل الاجتماعي معهم ، ويتحكم في سلوكه اللفظي وغيــر اللفظي فيها ويعدله كداله لمتطلباتها على نحو يساعد على تحقيق أهدافه " . كمــا تعرف " المهار ات الاجتماعية علي أنها" القدرة على قر اعة وفهم كل من السلوك الاجتماعي ، ومهارة المشاركة الاجتماعية ، منل التعبير اللفظـي و الانفعـالي ، و القدرة على لعب الدور الاجتماعي بكفاءة " . ( أمل حسونة ، منى أبو ناثــي ، $\cdot(T \cdot: \cdot .7$

يتضح مما سبق صعوبة تحديد مفهوم المهار ات الاجتماعية بدرجة كبيــرة من الوضوح و الدقة ، نظر اً لما قدمه العلماء و الباحثون مــن تعريفــات متعـددة لمفهوم المهار ات الاجتماعية ، ويرجع ذلك إلي اختلاف المهــار ات الاجتماعيــة المطلوبة باختلاف الموقف وما يحدث فيه من تفــاعلات و إدر الك الفــرد لـــللك الموقف وطريقة أدائه و استجابته ، مما يتطلب مستوي معيناً من التتظيم العقلـي ودي 
و الاتفعالي و المعرفي ، وبالر غم مــن تتعـدد الآر اء حــول مفهـوم المهـار ات

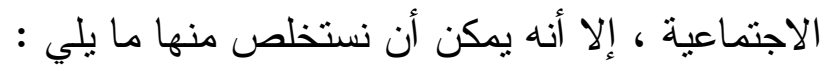

أن المهار ات الاجتماعية تتضمن سلوكيات لفظية وغير لفظية .

تؤكد هذه التعريفات علي أهية التعلم في اكتساب المهــار ات الاجتماعيــة

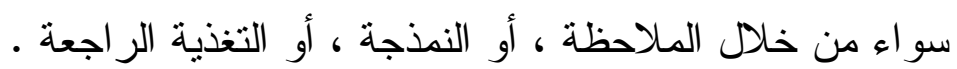

وتعرف الباحثة المهار ات الاجتماعية علي أنها قدرة الفرد علي اكتـساب

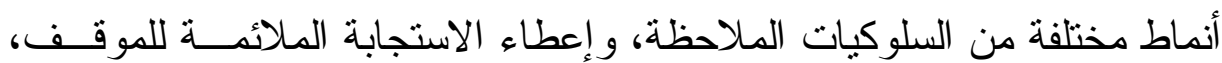
سو اء بصورة لفظية أو غير لفظية أثناء التفاعل مع عناصر بيئته.

\section{مكونات المهارات الاجتماعية :}

تمنل المهار ات الاجتماعية بمكوناتها الفرعية المختلفة متغيرًا نفسياً هامــاً

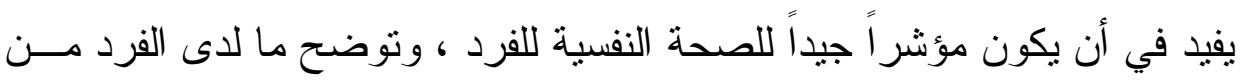

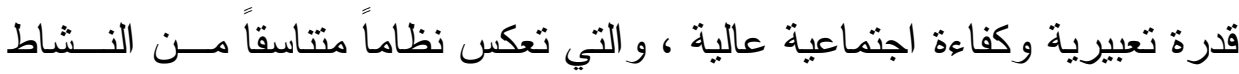
الذي يستهدف الفرد منه تحقيق هدف معين عندما يتفاعل مع الآخرين ـ (زينـبـ

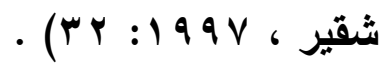

هذا وقد تناول العدبد من الباحثن عناصر أو مكونات المهارات الاجتماعية من زورابا متعددة .

\section{1 - تصنيف Riggio عام .99 199 لمكونات المهار ات الاجتماعية :}

و الذي برى أن المهار ات الاجتماعية هي مهار ات اتصال اجتماعي وتتقسم

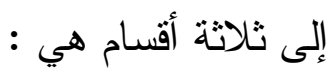




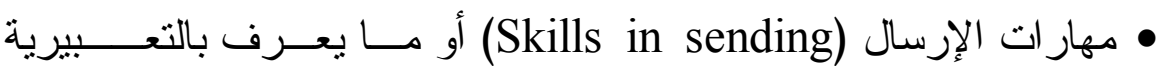
وتُشير إلى المهارة التي يتصل بها الأفر اد معاً .

• مهار ات في الاسنقبال (Skills in receiving) أو ما يعرف بالحسساسية

وتعبر عن المهارة التي نفسر بهـا صــيخ أو رســائل

$$
\text { • التو اصل مع الآخرين عن العهارة (Messages) }
$$

• Skills in Regulating or ) مهـار ات الــتحكم و الــضبط و التنظــيم

(controlling

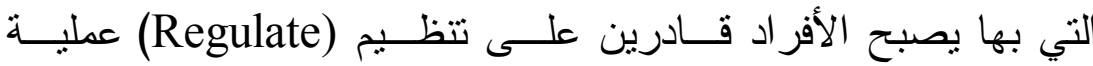

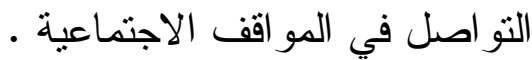

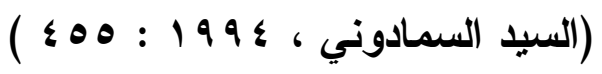

وهذه المهار ات الاتصالية الثلاث تظهر في جانبين من جوانب السلوك هما : • الجانب الاجتماعي ويختص بالاتصال اللفظي .

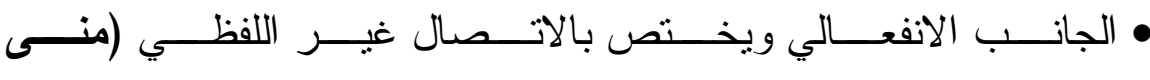

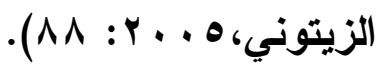

r - يصنف بيلاك وآخرون المهارة الاجتماعية إلى ثلاث مكونات هي :

أ- مهار ات الإدراك الاجتماعي:

الفرد الذي لديه مهار ات الإدر الك الاجتماعي هو الثخص الذي يستطيع أن

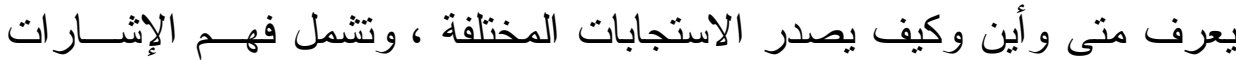

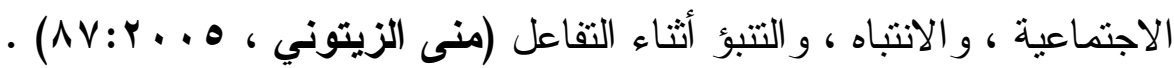




\section{ب- مهار ات المحادثة :}

الفرد الذي لديه مهار ات المحادثة هو الثخص الــذي يـستطيع أن يـــــأ

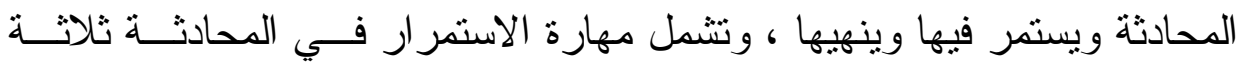

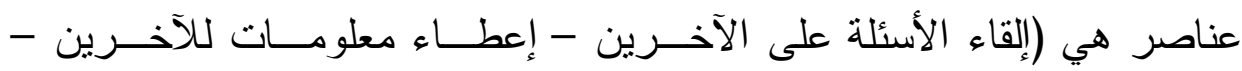

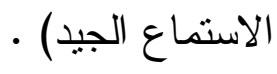

\section{ج- المهار ات التوكيدية :}

الفرد الذي لديه المهار ات التوكيدية هو الثخص الذي يــستطيع أن يعبـر بحرية عما يريد ، وتقسم المهار ات التوكيدية إلى نوعين لهما لهية :

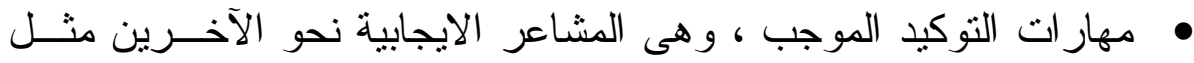

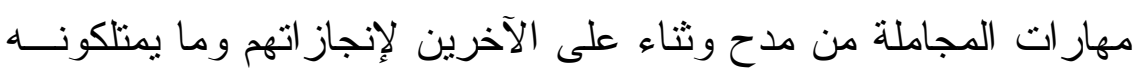

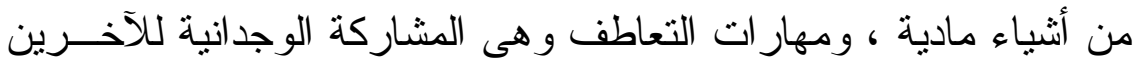

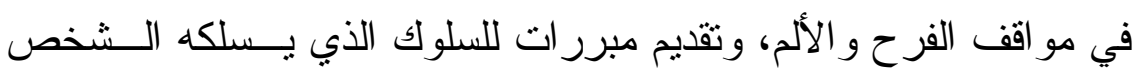
عندما يخطئ في حق الآخرين .

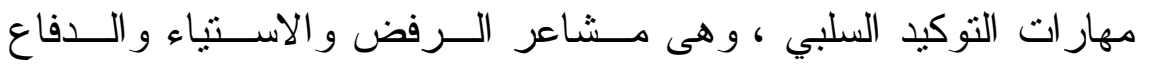

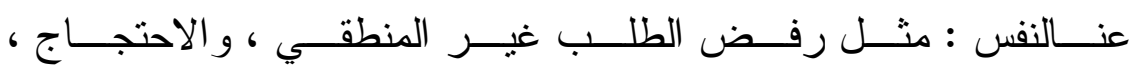

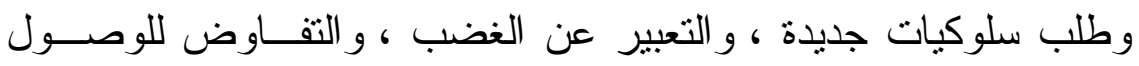

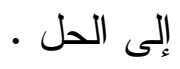

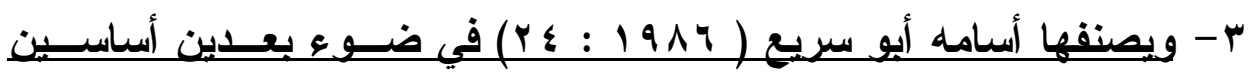

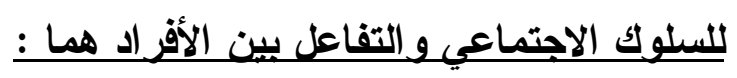

$$
\text { أ- بعد الحب في مقابل الكراهية : }
$$

ويعكس القدرة على إقامة علاقات مع الآخرين (مهارة الصداقة) ـ ويتحدد السلوك الاجتماعي للفرد باعتباره محصله للتفاعل بين هذئ الفين البعدين.

المجلد السادس




\section{ب - بع السبطرة في مقابل الخضوع : \\ ويعكس قدرة الفرد على توكيد ذاته (مهارة توكيد الذات) . \\ ع - و بصنفها طريف شوقي (r . . r، . - - 10) إلمى : \\ أ- المهار ات الاتصالبة : \\ وتتقم بدور ها إلى قسمين : \\ • مهيار ات استقبال :}

وتعنى مهارة الفرد في الانتباه وتلقى الرسائل اللفظية وغير اللفظيــة مــن

$$
\begin{aligned}
& \text { الآخرين ، و إدر اكها وفهم مغز اها ، و التعامل في ضوئها . } \\
& \text { مهار ات إرسيال : }
\end{aligned}
$$

و هى تعبر عن قدرة الفرد على توصيل المعلومسـات التــي يرغــب فـي

نقلها للآخرين لفظيا أو غير لفظياً من خلال عمليات نوعية كالتحدث ، و الحـــو ار

$$
\text { ، و الإشار ات الاجتماعية . }
$$

\section{ب- مهار ات وجدانبة:}

وتسهم في تيسير إقامة علاقات وثثقة وودية مع الآخرين و إدارة التفاعـلـل

معهم على نحو يساعد على الاقتز اب منهم و التقرب إليهم ليصبح الثخص أكثــر قبو لاً لديهم • ومن المهار ات الرئيسية في هذا السياق التعـاطف ، و والمـشـاركة

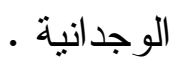

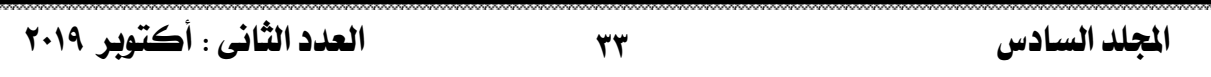




\section{ج- مهارات الضبط و المرونة الاجتماعية والافعالية :}

وهى تُشير إلى قدرة الفرد على التحكم بصورة مرنة في سلوكه اللفظـي

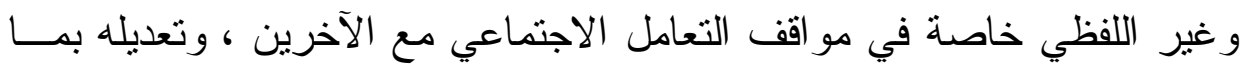

يتتاسب مع ما يطر أ على تللك المو اقف من مستجدات لتحقيق أهداف الفرد .

\section{د - ميهارة توكيد الذات :}

وتتعلق بمهارات التعبير عن المشاعر والآراء والدفاع عن الحقوق وتحديد

$$
\text { الهوية، وحمايتها، ومو اجهة ضغوط الآخرين • }
$$

ه- وقد حدد محمــ عبــ الـرحمن (1991 : 19) مكونــات المهـارتات

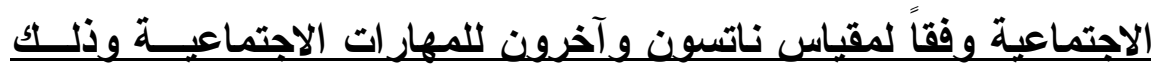

$$
\text { على النحو التالي : }
$$

\section{أ- التعبيز عن المشاعر الإيجابية :}

وتعنى القدرة على إقامة علاقات اجتماعية ناجحة من خلال التعبير عـن

$$
\begin{aligned}
& \text { الرضا عن الآخرين ومجاملتهم ، ومشاركتهم الحديث . } \\
& \text { ب- التعير عن المثاعر السلبية: }
\end{aligned}
$$

وتعنى القدرة على التعبير عن المشاعر لفظي أو غير لفظـي كاســتجابة

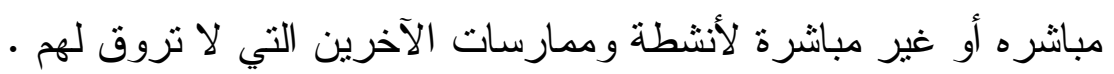

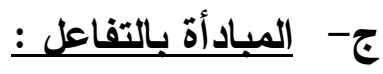

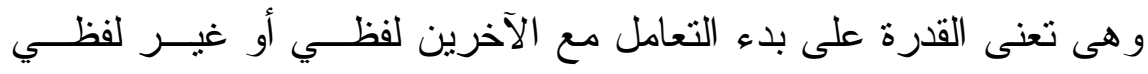

كالتعرف عليهم أو مد يد العون لهم أو زيارتهم أو تخفيف ألآمهم أو إضحاكهم.

r

المجلد السادس 


\section{د- الضبط الاجتماعي الإفعالي :}

وتعنى القدرة على النتروي وضبط الانفعالات في مو اقــف التفاعـل مــع الآخرين وذللك في سبيل الحفاظ على رو ابطه الاجتماعية .

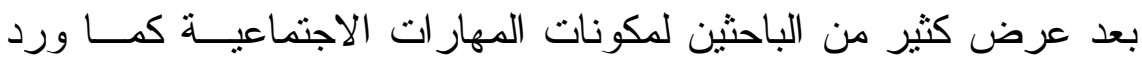

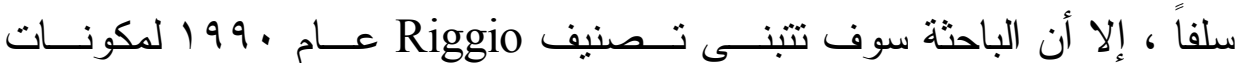
المهار ات الاجتماعية الثلاث و التي تظهر في جانبين من جوانب السلوك هما : الجانب الاجتماعي ويختص بالاتصال اللفظي .

الجانب الانفعالي ويختص بالاتصال غير اللفظـي • (منــــ الزيتــــي ،

$$
\text { . }(\wedge \wedge: r \ldots
$$

وفيما يلي سنتناول مهارات الاتصال اللفظي وغير اللفظي بثيء من التفصيل :

$$
\text { 1- الاتصال اللفظي }
$$

يتضمن هذا النوع من وسائل الاتصال كل أنو اع الاتصال التـي تـستخدم اللفظ كوسيلة لنقل رسالة من مرسل إلى مستقبل ـ وهذا اللفظ في الأصل منطوقاً

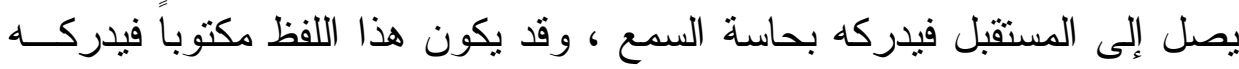

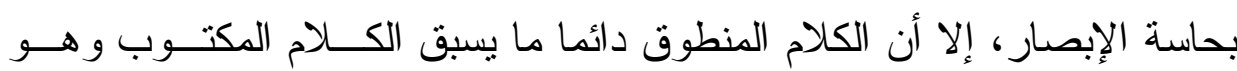

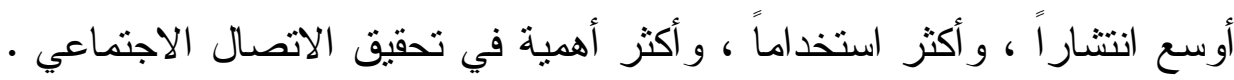

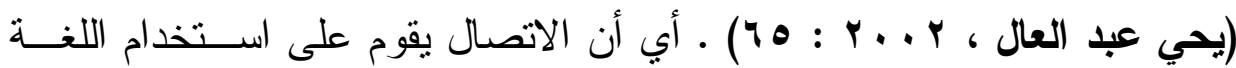

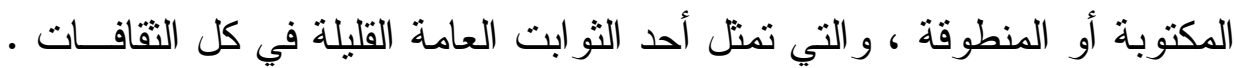

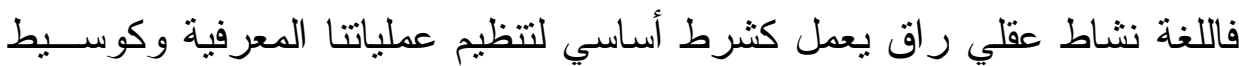

المجلد السادس


حتمي للاتصال الإنساني ، وكنظام من الرموز تحقق اللغة وظيفتين متكــاملتين

الوظبفة الاتصالية حيث تعمل اللغة كوسيط للتفاعل بــين الأفــر اد لنقـلـ

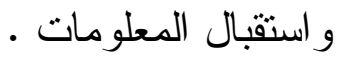

الوظيفة التجريدية فاللغة وسيلة لتكوين الأفكار التي تجرد الو اقع وتختزله

في شكل رموز تمكن الإنسان مــن فهمــهـه وضــبطه بدرجــة أكبــر •

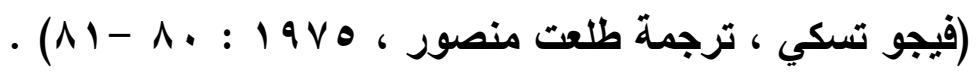

وتعتمد لغة التحدث بين الأشخاص على ما لديهم من معلومات اجتماعيــة مشتركة في مو اقف التفاعل ، ويؤدى ذلك إلى أن يصبح الاتصال أكثر اقتـصاداً

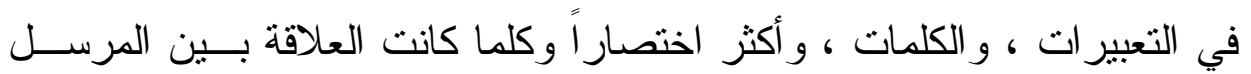

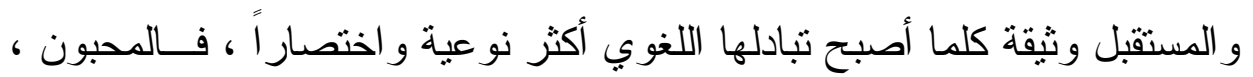
و الأصدقاء ، و الأسر ، ينمو لايهم شفر ات لغوية خاصة قد لا تكــون مفهومـــة تماماً لمن هم خارج هذه الجماعات . وفي نظرية حديثة عن كيفية اكتساب اللغة يؤكد برونر على أن تعلم مهار ات التفاعل الاجتماعي وتعلم اللغة يرتبطان معــاً بشكل كبير ، وأن الأطفال تعرف كيف تتفاعل قبل أن تعرف كيف تــتكلم ، هــذـا التفاعل الاجتماعي السابق على ظهور اللغة هو المسئول عن ســرعة اكتـساب اللغة بمجرد نضج الاستعداد ـ و المعرفة التامة باللغة لا تتطوي فقط على معرفة

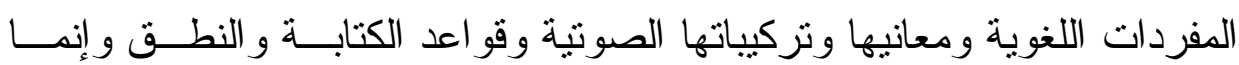
ينطوي على معرفة ما يقال و أين يقال وكيف يقال ولمن يقال .

ويستلزم ذلك أن يمتلك الثخص عدة مهار ات اجتماعية تتلخص فيما يلي : المودة - الحفاظ على تقدير الذات لطرفا التقاعل - تجنــب صـــيخة الإجبــار -

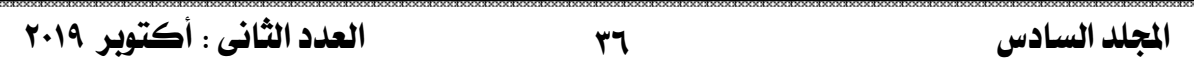


كيف تقول لا : التعبير عن عدم الموافقة - إصلاح الخطأ - عدم الخروج عـن

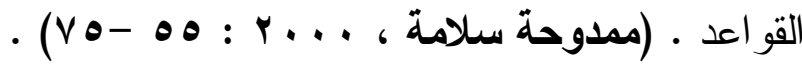

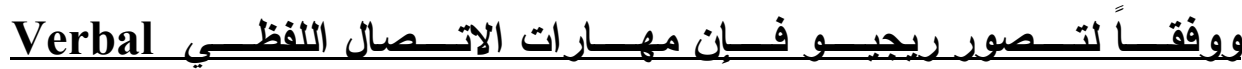
communication skills

$$
\text { • • الحساسية الاجتماعية . التعبير الاجتماعي • }
$$

\section{أ- الحساسية الاجتماعية Social Sensitivity}

وتعنى القدرة على استقبال وفهم رموز الاتــصـال اللفظــي ، و المعرفــة

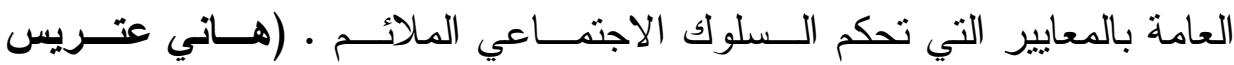
. ( 1 : :199V،

فهي بهذا المعنى وكما يذكر ريجيو ، 199 تعنى القدرة على فهم قو اعـــ

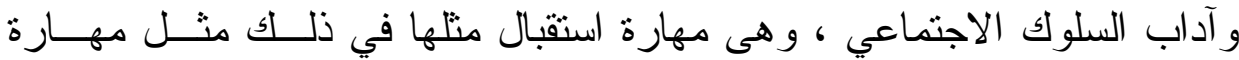

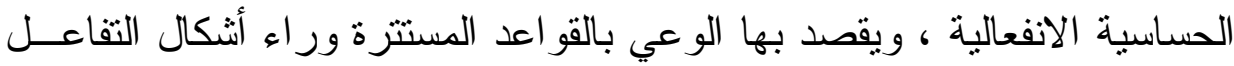

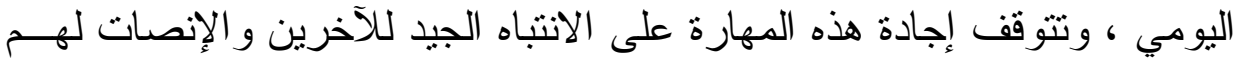
وملاحظة سلوكهم جيداً ، إذ أن ذلك يجعـل الفـرد أكثـر حسـساسية لاســنقبال الإثشار ات الصادرة في مو اقف التفاعل الاجتماعي ، و التي قد يغفلها شخص آخر

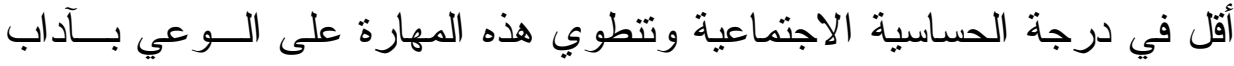

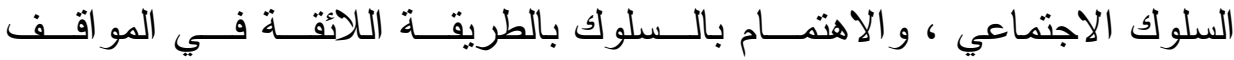

المجلد السادس


الاجتماعية ، و هذه المهارة تجعل الأشخاص الذين يجيدونها يبـدون للأثــخاص

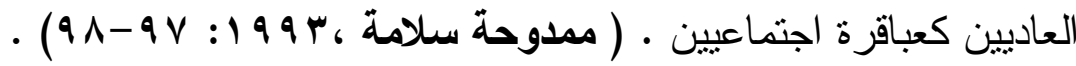

\section{ب-التعبير الاجتماعي Expressivity Social}

يُشير إلى مهارة التعبير اللفظي ، أي القدرة علـى الاتـصال باسـتخدام

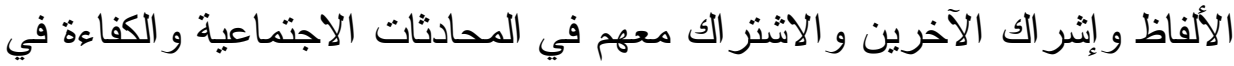
بدء وتوجيه الحوار ـ الأمر الذي يمكنهم من إقامة علاقات وصداقات متعددة . وقد أطلق عليها ريجيو Riggio عام 9191 مهارة الإرسال وأوجزها في

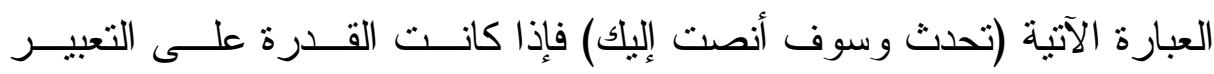
الانفعالي تتطوي على تلقائية وصدق المشاعر و التعبير غير اللفظي عنها ، فــأن القدرة على التعبير الاجتماعي هي القدرة على التعبير اللفظي ، و القادرين علــى التيل

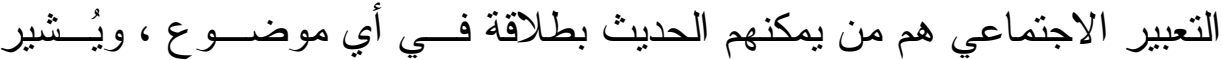

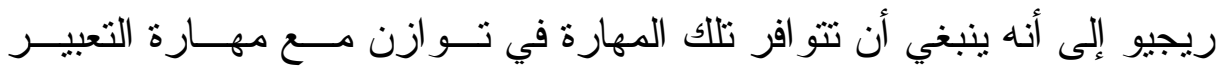
الانفعالي و الحساسية الانفعالية ، و الضبط الانفعالي ، و إلا قد ينشأ عنهـــا آتــار

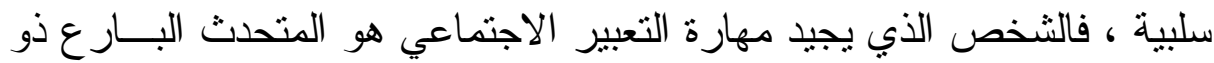
الطلاقة اللغوية الذي يستطيع أن يسيطر على الحديث ، ولكن إذا كانت تتقـــهـ

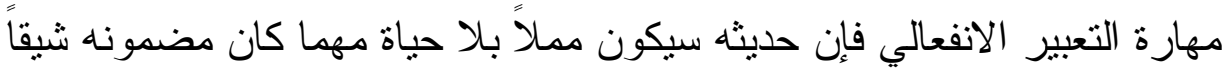
، حيث لا تكفى إجادة الحديث و الطلاقة اللغوية لتخلق القدرة على التـأثير فــي لـاني

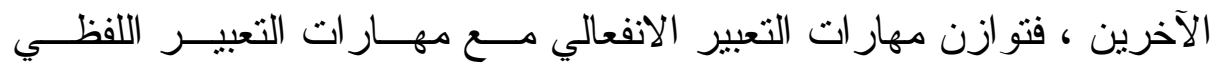

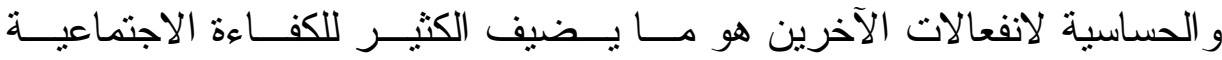

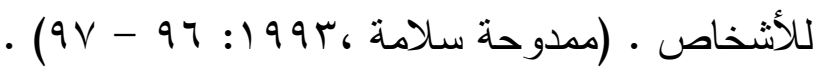




\section{ج- الضبط الاجتماعي Social Control}

Social self - من منظور ريجيو يعكس الحضور الاجتمــــي للـــات

Riggio,1986: ) مستوى مهارة الفرد في الضبط الاجتماعي presentation

وأوجز ريجيو Riggio عام •199 هذه المهارة في "عبارة العالم مسسرح

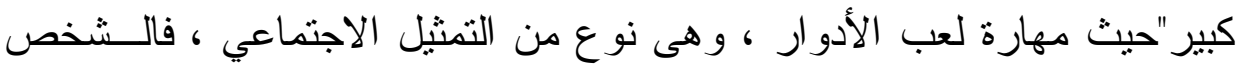

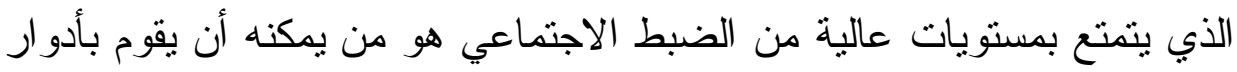

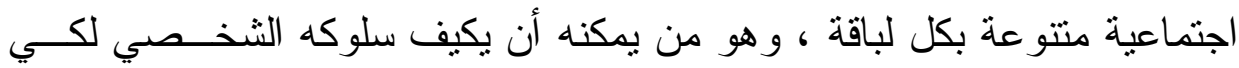

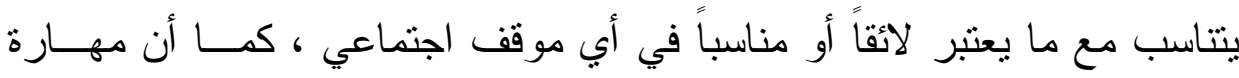

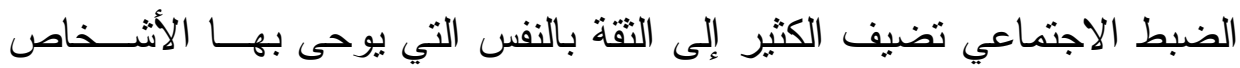

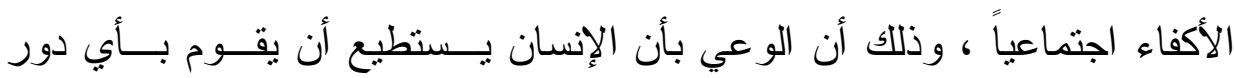

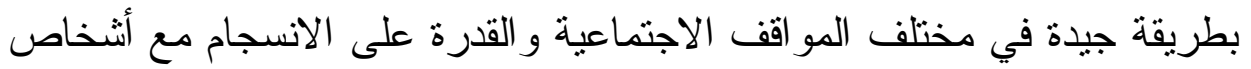

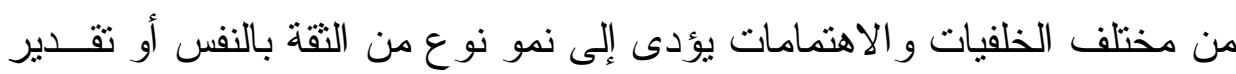

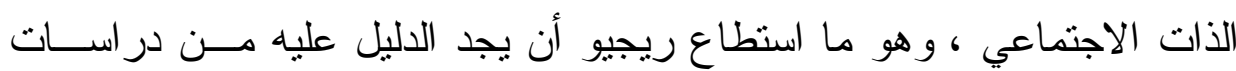
أمبيريقية قام بها ووجد من خلالها علاقة طردية موجبة بين الضبط الاجتمـاعي

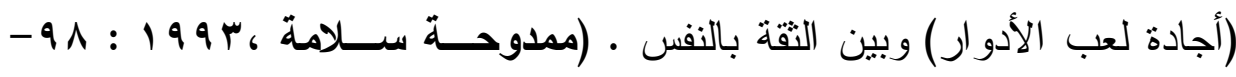


ا إبر اهيم قثقوش (910 (1) ) سيكولوجية المر اهقة ، الطبعة r ، القاهرة ، مكتبة الأنجلو المصرية . r. أبو بكر مرسي (997 (1) ) أزمة الهوية و الاكتئاب النفسي لدى الـشباب الجامعي ، مجلة در اسات نفسية ، القاهرة ، رابطة الأخصائيين النفسيين المصرية ، المجلد V ، العدد r ، ص ص ، بrس-ror .

r. عبد الستار إبر اهيم (991 (1)) ـ الاكتئاب - اضطر اب العصر الحـديث ، الكويت ، سلسة عالم المعرفة ، المجلس الوطني للتقافة و الفنون و الآداب

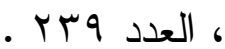

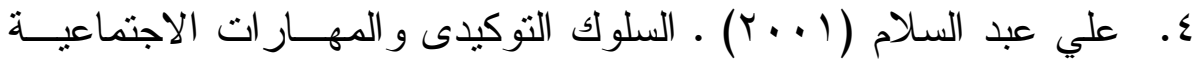
و علاقتهما بالسلوك الانفعالي للغضب بين العاملين و العـاملات ، مجلـــة علم النفس ، القاهرة ، الهيئة المصرية العامة للكتاب ، المجلد ب ، العدد

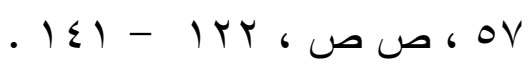

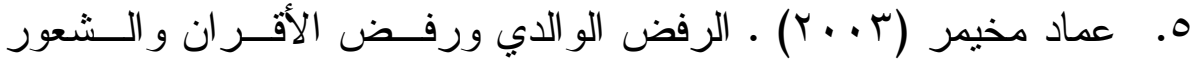
بالوحدة النفسية في المر اهقة ، مجلة در اسات نفسية ، القاهرة ، رابطــة

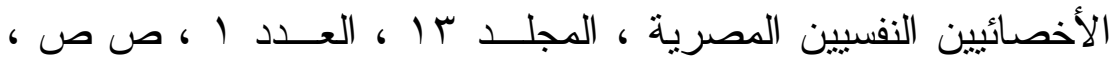

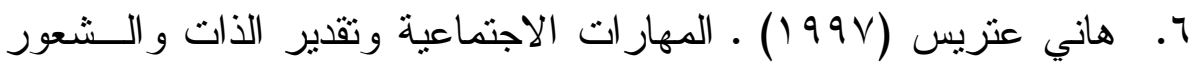
بالوحدة النفسية لاى طلاب الجامعة ، رسالة ماجستير غير منـشورة ، كلية الآداب ، جامعة الزقازيق • 


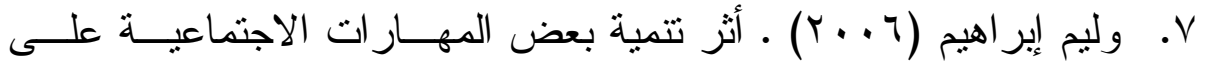

تحسين الأداء و التو افق المهني و الرضا الوظيفي لدى المرضى ، رســالة

ماجستير غير منشورة ، كلية الآداب ، جامعة عين شمس •

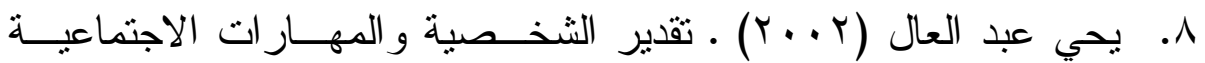

و ارتباطهما بالاضطر ابات الـسيكوسوماتية ، رســالة ماجسـتير غيــر

منشورة ، كلية الآداب ، جامعة الزقازيق •

1. Dianne, M., \& Stephen, P. (2002). Cooperative learning and social stories: Effective social skills strategies for reading teachers. Journal of Personality and Individual Differences, Vol. 18, pp. 87 $-91$.

2. Hayes, M. (1994). Social skills, national center for learning disabilities. New York

3. Librman, R., Derisi, W., \& Mueser, K. (1989). Social skills training for psychiatric patients, psychology practitioner guide books. United States of American: Allyn \&Bacon. A division of Simon \& Schuster, Inc. 